\title{
KEMAMPUAN BERPIKIR LOGIS DAN MODEL MENTAL KIMIA SEKOLAH MAHASISWA CALON GURU
}

\author{
Wiji, Liliasari, Wahyu Sopandi, dan Muhammad A. K. Martoprawiro \\ FPMIPA UPI, Sekolah Pascasarjana UPI, Jurusan Kimia ITB \\ email: masswiji@yahoo.com
}

\begin{abstract}
Abstrak: Tujuan penelitian ini adalah untuk mengungkapkan apakah ada perbedaan yang signifikan dalam kemampuan berpikir logis mahasiswa calon guru dan model mental kimia sekolah berdasarkan pada tingkat nilai mereka. Penelitian ini juga dimaksudkan untuk mengetahui apakah kemampuan berpikir logis berkorelasi dengan model mental kimia sekolah. Penelitian ini dilakukan dengan metode cross-section yang meliputi 124 mahasiswa calon guru kimia yang sedang mengikuti kuliah di program studi Pendidikan Kimia di sebuah LPTK di Bandung. Data dikumpulkan dengan tes kemampuan berpikir logis dan tes diagnostik model mental kimia sekolah. Tes kemampuan berpikir logis meliputi lima skala: penalaran proporsional, variabel kontrol, penalaran kombinasi, penalaran probabilistik, dan penalaran korelasional. Tes diagnostik model mental kimia sekolah mencakup lima masalah: stoichiometry, thermochemistry, chemical equilibrium, tingkat reaksi, dan asam-basa. Temuan penelitian menunjukkan bahwa berdasarkan tingkat nilai mahasiswa, terdapat perbedaan yang signifikan pada rerarta model mental kimia sekolah, tetapi tidak pada rerata kemampuan berpikir logis. Temuan penelitian juga menunjukkan bahwa tingkat kemampuan berpikir logis para guru kimia berkorelasi dengan model mental kimia sekolah.
\end{abstract}

\section{Kata Kunci: kemampuan berpikir logis, model mental kimia sekolah, metode cross-section, mahasiswa calon guru kimia}

\section{THE LOGICAL THINKING ABILITY AND THE MENTAL MODEL OF SCHOOL CHEMISTRY OF TEACHERS-TO-BE}

\begin{abstract}
The purpose of this researchwas toreveal if there was any significant difference in students' logical thinking abilities and mental models of school chemistry based on their grade level. This study was also aimed to investigate whether the logical thinking ability was correlated with the mental models of school chemistry. The study was conducted using the cross-section method and included 124 teachers-to-be who were students in the department of chemistry education at a university of teachers training in Bandung. The data were collected through the test of logical thinking (TOLT) and the diagnostic test of school chemistry mental models (DTSCM). The TOLT instrument included five subscales: proportional reasoning, controlling variables, combinational reasoning, probabilistic reasoning, and correlational reasoning. The DTSCM instrument included five sub-matters: stoichiometry, thermochemistry, chemical equilibrium, rate of reaction, and acid-base. Research findings showed that based on students' grade level, there was a significant difference in themean of mental models of school chemistry but not in the mean of logical thinking abilities. The findingsalso indicated thatthe logical thinking level ofthe teachers-to-be was correlated with the mental models of school chemistry.
\end{abstract}

Keywords: logical thinking ability, mental models of school chemistry, cross-section method, teachers-to-be

\section{PENDAHULUAN}

Ilmu kimia merupakan salah satu cabang ilmu yang mempelajari tentang susunan, komposisi, struktur, sifat-sifat dan perubahan materi, serta perubahan energi yang menyertai perubahan-perubahan materi tersebut. Fenomena yang berhubungan dengan materi dan perubahannya dapat diamati secara makroskopik, dijelaskan secara sub-mikroskopik dan direpresentasikan secara simbolik. Selama ini, penguasaan ilmu kimia mahasiswa calon guru secara umum dievaluasi menggunakan alat ukur yang 
sederhana, seperti tes pilihan ganda atau tes uraian. Alat ukur tersebut dirasa belum maksimal karena cenderung mengukur pengetahuan siap saji. Oleh karena itu, perlu dikembangkan soal-soal yang mampu mengeksplorasi apa yang ada dalam pikiran mahasiswa terkait dengan konsep-konsep yang diujikan. Tes semacam ini sering dikenal dengan istilah tes diagnostik model mental. Banyak cara dilakukan oleh berbagai peneliti dalam mengeksplorasi model mental, di antaranya melalui pemberian soal secara gabungan, baik pilihan ganda beralasan, uraian, maupun wawancara dan observasi kelas (Lin and Chiu, 2007; Coll, 2008; Park and Light, 2009; Jansoon, Coll and Somsook, 2009; Adbo and Taber, 2009; Strickland, Kraft and Bhattacharyya; 2010; Wang and Barrow, 2010; Lin and Chiu, 2010).

Penguasaan materi subjek sains, termasuk kimia dapat diprediksikan berdasarkan kemampuan berpikir logis (Valanides, 1997; Yilmaz and Alp, 2006; Fah, 2009). Pembelajaran kimia membutuhkan keterampilan intelektual, seperti mengumpulkan dan menganalisis data untuk memecahkan masalah, merumuskan hipotesa, mengendalikan variabel serta mendefinisikan secara operasional. Proses-proses tersebut membutuhkan kemampuan berlogika tingkat tinggi. Mengingat pentingnya hal tersebut, beberapa penulis telah mendesak untuk menjadikan pengembangan kemampuan berlogika sebagai prioritas utama dalam ilmu pendidikan (Savant, 1997). Pembelajar dengan tingkat kemampuan berlogika yang baik dapat mengubah konsepsi alternatifnya dengan lebih mudah (Oliva, 2003). Hasil penelitian Lawson dan Thompson (1988) menunjukkan bahwa polapola kemampuan berlogika diperlukan untuk penghapusan beberapa miskonsepsi dalam pembelajaran biologi. Kemampuan berpikir logis telah teridentifikasi sebagai kemampuan yang sangat esensial untuk menunjang perkembangan pembelajaran sains dan matematika (Adey \& Shayer, 1994).

Kemampuan berpikir logis meliputi lima jenis penalaran, yaitu proporsional, pengontrolan variabel, probabilitas, korelasional, dan kombinatorial (Inhelder \& Piaget, 1958). Penalaran proporsional penting dalam aspek kuantitatif kimia, terutama untuk memahami derivasi dan penggunaan sejumlah besar hubungan fungsional dalam kimia, seperti pengembangan dan interpretasi data tabulasi dan grafik. Penalaran korelasional berperan dalam perumusan hipotesis dan interpretasi data yang perlu mempertimbangkan hubungan antarvariabel. Pengontrolan variabel penting dalam perencanaan, pelaksanaan dan interpretasi. Interpretasi data dari temuan, pengamatan, atau percobaan sering membutuhkan penalaran probabilistik. Penalaran kombinatorial terjadi dalam perumusan hipotesis alternatif untuk menguji efek variabel yang dipilih.

Tobin \& Capie (1981) telah mengembangkan alat ukur kemampuan berpikir logis dalam bentuk pilihan ganda beralasan, yaitu Tes of Logical Thinking (TOLT). TOLT telah digunakan secara luas dalam pembelajaran dan penelitian. TOLT dapat digunakan untuk mengetahui kemampuan berpikir logis siswa sekolah dasar dan sekolah menengah sampai mahasiswa perguruan tinggi. TOLT juga telah digunakan untuk memeriksa apakah proses belajar mengajar yang dilakukan dapat meningkatkan kemampuan berpikir logis mahasiswa. Hasil skor TOLT dapat digunakan sebagai dasar untuk mengklasifikasikan responden ke dalam tahapan perkembangan kognitif, seperti yang telah dikembangkan oleh Piaget. Skor total 0-1 bersesuaian dengan tahap perkembangan konkret, 2-3 bersesuaian dengan tahap perkembangan transisional, dan 4-10 bersesuaian dengan tahap perkembangan formal. Valanides (1997) membagi tahap perkembangan formal menjadi dua sub tahap, yaitu tahap operasional formal (skor 4-7) dan formal akhir (skor 8-10).

Penelitian ini dilakukan dengan tujuan seperti berikut. (1) Mendeskripsikan kemampuan berpikir logis dan model mental kimia sekolah dari mahasiswa calon guru kimia, (2) Mengetahui perbedaan kemampuan berpikir logis dan model mental kimia sekolah berdasarkan tingkat kelas. (3) Mengetahui korelasi jenis-jenis penalaran dalam kemampuan berpikir logis dengan setiap pokok bahasan dalam model mental kimia sekolah. 


\section{METODE}

Penelitian ini dilakukan menggunakan metode kuantitatif non eksperimen, dengan desain survei lintas-bagian (cross-sectional survey). Kecenderungan kemampuan berpikir logis dan model mental kimia sekolah mahasiswa calon guru kimia dideskripsikan berdasarkan sampel penelitian.

Sampel penelitian terdiri atas mahasiswa calon guru kimia pada tingkat I, II, III, dan IV, Jurusan Pendidikan Kimia pada salah satu universitas penghasil guru di Bandung. Jumlah total sampel adalah 124 orang mahasiswa, terdiri atas tingkat I sebanyak 39 orang, tingkat II sebanyak 26 orang, tingkat III sebanyak 35 orang, dan tingkat IV sebanyak 24 orang.

Pada penelitian ini digunakan dua instrumen penelitian yang meliputi Tes Kemampuan Berpikir Logis (TKBL) dan Tes Diagnostik Model Mental Kimia Sekolah (TDMKS).

TKBL untuk mahasiswa calon guru kimia dimodifikasi dan diterjemahkan dari TOLT (Tobin \& Capie,1981). Tes ini terdiri dari 10 butir soal yang meliputi lima jenis kemampuan berpikir logis, yaitu penalaran proporsional, pengontrolan variabel, penalaran probabilitas, penalaran korelasional, dan penalaran kombinatorial. TKBL dikembangkan dalam bentuk two tier multiple choice (pilihan ganda beralasan), kecuali untuk penalaran kombinatorial, responden diminta menuliskan berbagai kombinasi yang mungkin dari beberapa variabel. Pada penalaran proporsional, mahasiswa dihadapkan pada pernyataan empat buah jeruk besar yang dapat diperas menjadi enam gelas air jeruk. Selanjutnya, ditanyakan berapa gelas air jeruk dapat diperoleh dari enam buah jeruk besar dan berapa buah jeruk yang diperlukan untuk membuat 13 gelas air jeruk.

Pertanyaan pengontrolan variabel diawali dari gambar 5 buah pendulum dengan variasi panjang tali dan berat beban. Selanjutnya, mahasiswa diminta memilih rancangan percobaan untuk meneliti apakah perubahan panjang tali pendulum dan perubahan beban pada ujung tali akan mengubah waktu ayun pendulum. Pada penalaran probabilitas, mahasiswa dihadapkan pada data sekumpulan benda. Selanjutnya, me- reka diminta untuk memprediksikan probabilitas ketika mengambil salah satu benda tersebut. Pertanyaan untuk mengukur penalaran korelasional diawali dengan gambar sejumlah tikus dan ikan dengan ciri-ciri yang bervariasi. Selanjutnya, mahasiswa diminta untuk memilih kecenderungan ciri-ciri tikus dan ikan yang gemuk. Pada penalaran kombinatorial, mahasiswa diminta untuk membuat kombinasi yang mungkin dari 3 dan 4 buah data.

Validitas TKBL ditingkatkan dengan melakukan serangkaian tahapan seperti berikut. (1) TOLT diterjemahkan ke dalam Bahasa Indonesia secara terpisah oleh dosen kimia dan dosen bahasa Inggris. Selanjutnya, dibandingkan dan dilakukan modifikasi untuk menghindari kesalahan struktur bahasa dan peristilahan (TKBL Draft 1). (2) TKBL Draft 1diberikan kepada dosen kimia dan dosen bahasa Inggris yang lain untuk diterjemahkan ke dalam Bahasa Inggris (TKBL Draft 2). (3) TOLT dalam bahasa Inggris yang asli dibandingkan dengan TKBL Draft 2 dan dilakukan modifikasi peristilahan sehingga makna bahasa tetap terjaga. Nama personal yang tercantum dalam soal disesuaikan dengan nama yang dikenal di Indonesia (TKBL Draft 3). (4) dilakukan uji keterbacaan TKBL Draft 3 kepada mahasiswa calon guru kimia dan dilakukan modifikasi sehingga didapatkan TKBL yang mudah dimengerti.

Uji reliabilitas instrumen TKBL menggunakan Alpha Cronbach dan didapatkan koefisien reliabilitas sebesar 0,772 untuk total soal dan antara 0,697 sampai 0,955 untuk setiap jenis kemampuan berpikir logis. Reliabilitas terendah pada penalaran korelasional dan tertinggi pada penalaran proporsional.

TDMKS dikembangkan dari materi subjek kimia sekolah yang dipersepsikan sulit. Tes terdiri atas 10 butir pertanyaan dalam bentuk two tier tes yang meliputi empat pilihan jawaban dan enam pilihan alasan. Pilihan alasan terdiri atas lima pilihan tertutup dan satu pilihan terbuka. Alasan disajikan dalam bentuk model simbolik dari fenomena sub-mikroskopik dan makroskopik. Materi subjek yang diujikan meliputi konsep reaksi kimia dan pereaksi pembatas untuk materi subjek stoikiometri, konsep 
energi aktivasi dan entalpi reaksi untuk materi subjek termokimia, konsep kecepatan reaksi dan teori tumbukan untuk materi subjek kecepatan reaksi, konsep kesetimbangan dinamis, dan tetapan kesetimbangan untuk materi subjek kesetimbangan, serta konsep titrasi dan perbandingan sifat asam untuk materi subjek asam basa.

TDMKS telah dinyatakan valid oleh tiga orang dosen jurusan pendidikan kimia dengan latar belakang seorang doktor bidang kimia fisi$\mathrm{ka}$, seorang doktor bidang pendidikan kimia, dan seorang doktor yang telah berpengalaman mengajar kimia dasar dan kimia sekolah. Selain itu, juga telah soal dinyatakan mudah dimengerti oleh mahasiswa ketika uji coba.

Uji reliabilitas instrumen TDMKS menggunakan Alpha Cronbach dan didapatkan koefisien reliabilitas sebesar 0,798 untuk total soal dan antara 0,676 sampai 0,779 untuk setiap pokok bahasan model mental kimia sekolah. Reliabilitas terendah pada pokok bahasan asam basa dan tertinggi pada stoikiometri.

Data penelitian dikumpulkan menggunakan instrumen TKBL dan TDMKS dan diolah menggunakan statistik deskriptif dan inferensial. Statistik deskriptif digunakan untuk menggambarkan rata-rata skor dan simpangan baku TKBL dan TDMKS per tingkat kelas, baik secara total maupun per bagian. Selanjutnya, berdasarkan skor TKBL, mahasiswa dikelompokkan menurut tahap perkembangan kognitif Piaget. Statistik inferensial untuk mengidentifikasi perbedaan skor rata-rata setiap tingkat kelas, baik untuk kemampuan berpikir logis maupun model mental kimia sekolah. Uji statistik yang digunakan adalah uji non parametrik Kruskal Wallis karena data tidak berdistribusi normal. Statistik inferensial juga digunakan untuk menguji korelasi antara kemampuan berpikir logis dengan model mental kimia sekolah. Uji korelasi yang digunakan adalah uji bivariate Spearman.

\section{HASIL DAN PEMBAHASAN}

\section{Kemampuan Berpikir Logis Mahasiswa}

Kemampuan berpikir logis mahasiswa calon guru kimia berdasarkan tingkat kelas da- pat dilihat dalam Tabel 1. Kemampuan berpikir logis mahasiswa cenderung semakin meningkat berdasarkan kenaikan tingkat kelas. Total ratarata kemampuan berpikir logis mahasiswa tingkat I, II, III dan IV adalah 4,90 (SD = 3,243); $5,04(\mathrm{SD}=3,493) ; 5,31(\mathrm{SD}=3,554)$; dan 6,71 $(\mathrm{SD}=3,085)$ secara berurutan. Penalaran proporsional memiliki skor rata-rata yang paling tinggi $(1,20)$, sedangkan penalaran probabilitas memiliki skor rata-rata yang paling rendah $(1,00)$. Mahasiswa tingkat I sampai dengan III didominasi oleh kemampuan penalaran proporsional, sedangkan mahasiswa tingkat IV didominasi oleh pengontrolan variabel. Secara keseluruhan, rata-rata skor kemampuan berpikir logis mahasiswa calon guru kimia adalah 5,40 dengan skor maksimal 10 dengan simpangan baku 3,383.

Pada Tabel 2, dapat dilihat distribusi kemampuan berpikir logis mahasiswa calon guru kimia berdasarkan skor. Pengelompokkan skor ke dalam rentang 0-1, 2-3, 4-7, dan 8-10 yang digunakan sebagai dasar untuk membagi mahasiswa ke dalam tahapan perkembangan kognitif Piaget, ditunjukkan dalam Tabel 3. Sebagian besar mahasiswa dari tingkat I sampai dengan tingkat IV sudah mencapai tahap perkembangan formal atau formal akhir. Prosentase tahap perkembangan kognitif formal akhir adalah $28,2 \%, 30,7 \%, 37,1 \%$, dan $54,2 \%$ untuk mahasiswa tingkat I, II, III, dan IV secara berurutan. Sebagaimana diharapkan, semakin tinggi tingkat kelas semakin banyak yang mencapai tahap perkembangan formal atau formal akhir.

\section{Model Mental Mahasiswa tentang Kimia Sekolah}

Pada Tabel 4 ditunjukkan skor rata-rata model mental kimia sekolah dari mahasiswa calon guru kimia. Rata-rata skor model mental kimia sekolah adalah 41,85 dari skor maksimal 100 , dengan rata-rata skor tertinggi pada pokok bahasan thermokimia. Dari lima pokok bahasan yang diujikan, hanya pokok bahasan asam basa yang menunjukkan skor rata-rata semakin meningkat berdasarkan kenaikan tingkat kelas, yaitu $6,79(\mathrm{SD}=5,064) ; 7,31(\mathrm{SD}=3,530) ; 7,86$ $(\mathrm{SD}=4,894)$; dan $11,87(\mathrm{SD}=4,848)$ untuk tingkat I, II, III, dan IV secara berurutan. Mahasis- 
wa tingkat IV memiliki skor model mental kimia sekolah paling tinggi dibandingkan tingkat kelas dibawahnya, kecuali untuk pokok bahasan thermokimia. Mahasiswa tingkat II memiliki skor rata-rata tertinggi untuk pokok bahasan thermokimia yaitu $12,69(\mathrm{SD}=4,523)$.

Tabel 1. Nilai Rata-rata Kemampuan Berpikir Logis Mahasiswa Calon Guru Kimia

\begin{tabular}{|c|c|c|c|c|c|c|c|c|c|c|}
\hline \multirow[t]{2}{*}{ Jenis KBL } & \multicolumn{2}{|c|}{ Tingkat I } & \multicolumn{2}{|c|}{ Tingkat II } & \multicolumn{2}{|c|}{ Tingkat III } & \multicolumn{2}{|c|}{ Tingkat IV } & \multicolumn{2}{|c|}{ Total } \\
\hline & M & SD & M & SD & M & SD & M & SD & M & SD \\
\hline Penalaran proporsional & 1,13 & 0,894 & 1,12 & 0,766 & 1,26 & 0,817 & 1,33 & 0,702 & 1,20 & 0,806 \\
\hline Pengontrolan variabel & 0,97 & 0,903 & 1,08 & 0,845 & 1,11 & 0,832 & 1,42 & 0,717 & 1,12 & 0,842 \\
\hline Penalaran probabilitas & 0,90 & 0,821 & 0,92 & 0,796 & 0,91 & 0,781 & 1,38 & 0,770 & 1,00 & 0,806 \\
\hline Penalaran korelasional & 0,90 & 0,718 & 0,96 & 0,720 & 1,06 & 0,838 & 1,33 & 0,816 & 1,04 & 0,780 \\
\hline Penalaran kombinatorial & 1,00 & 0,795 & 0,96 & 0,824 & 0,97 & 0,923 & 1,25 & 0,737 & 1,03 & 0,826 \\
\hline Total & 4,90 & 3,243 & 5,04 & 3,493 & 5,31 & 3,554 & 6,71 & 3,085 & 5,40 & 3,383 \\
\hline
\end{tabular}

Tabel 2. Distribusi Skor Kemampuan Berpikir Logis Mahasiswa Calon Guru Kimia

\begin{tabular}{ccccccccccc}
\hline \multirow{2}{*}{ Skor } & \multicolumn{2}{c}{ Tingkat I } & \multicolumn{2}{c}{ Tingkat II } & \multicolumn{2}{c}{ Tingkat III } & \multicolumn{2}{c}{ Tingkat IV } & \multicolumn{2}{c}{ Total } \\
\cline { 2 - 11 } & $\mathrm{f}$ & $\%$ & $\mathrm{f}$ & $\%$ & $\mathrm{f}$ & $\%$ & $\mathrm{f}$ & $\%$ & $\mathrm{f}$ & $\%$ \\
\hline 0 & 5 & 12,8 & 3 & 11,5 & 4 & 11,4 & 2 & 8,3 & 14 & 11,3 \\
1 & 3 & 7,7 & 4 & 15,4 & 2 & 5,7 & 0 & 0,0 & 9 & 7,3 \\
2 & 1 & 2,6 & 0 & 0,0 & 2 & 5,7 & 0 & 0,0 & 3 & 2,4 \\
3 & 4 & 10,3 & 3 & 11,5 & 7 & 20,0 & 1 & 4,2 & 15 & 12,1 \\
4 & 6 & 15,4 & 1 & 3,8 & 0 & 0,0 & 4 & 16,7 & 13 & 10,5 \\
5 & 5 & 12,8 & 3 & 11,5 & 2 & 5,7 & 1 & 4,2 & 9 & 7,3 \\
6 & 3 & 7,7 & 2 & 7,7 & 0 & 0 & 2 & 8,3 & 12 & 9,7 \\
7 & 1 & 2,6 & 2 & 7,7 & 5 & 14,3 & 1 & 4,2 & 4 & 3,2 \\
8 & 2 & 5,1 & 3 & 11,5 & 2 & 5,7 & 4 & 16,7 & 11 & 8,9 \\
9 & 6 & 15,4 & 1 & 3,8 & 5 & 14,3 & 4 & 16,7 & 16 & 12,9 \\
10 & 3 & 7,7 & 4 & 15,4 & 6 & 17,1 & 5 & 20,8 & 18 & 14,5 \\
Total & 39 & 100,0 & 26 & 100,0 & 35 & 100,0 & 24 & 100,0 & 124 & 100,0 \\
\hline
\end{tabular}

Tabel 3. Persentase Mahasiswa Berdasarkan Perbedaan Tahap Perkembangan Kognitif

\begin{tabular}{ccccc}
\hline Tingkat Kelas & \multicolumn{4}{c}{ Persentase Tahap Perkembangan Kognitif } \\
\cline { 2 - 5 } & konkret & transisional & formal & formal akhir \\
\hline I & 20,5 & 12,9 & 38,5 & 28,2 \\
II & 26,9 & 11,5 & 30,7 & 30,7 \\
III & 17,1 & 25,7 & 20,0 & 37,1 \\
IV & 8,3 & 4,2 & 33,4 & 54,2 \\
Total & 18,6 & 14,5 & 30,7 & 36,3 \\
\hline
\end{tabular}

Tabel 4. Skor Rata-rata Model Mental Kimia Sekolah Mahasiswa Calon Guru Kimia

\begin{tabular}{lcccccccccc}
\hline \multirow{2}{*}{ Pokok Bahasan MKS } & \multicolumn{2}{c}{ Tingkat I } & \multicolumn{2}{c}{ Tingkat II } & \multicolumn{3}{c}{ Tingkat III } & \multicolumn{2}{c}{ Tingkat IV } & \multicolumn{2}{c}{ Total } \\
\cline { 2 - 12 } & M & SD & M & SD & M & SD & M & SD & M & SD \\
\hline Stoikiometri & 8,33 & 5,658 & 5,96 & 4,247 & 4,71 & 4,191 & 9,58 & 5,090 & 7,06 & 5,180 \\
Thermokimia & 6,15 & 4,049 & 12,69 & 4,523 & 10,57 & 5,392 & 12,29 & 4,418 & 9,96 & 5,315 \\
Kesetimbangan & 5,38 & 4,643 & 10,19 & 4,578 & 8,43 & 4,661 & 12,29 & 3,605 & 8,59 & 5,083 \\
Kecepatan Reaksi & 7,05 & 3,387 & 8,46 & 4,188 & 7,57 & 4,597 & 10,00 & 3,901 & 8,06 & 4,118 \\
Asam Basa & 6,79 & 5,064 & 7,31 & 3,530 & 7,86 & 4,894 & 11,87 & 4,848 & 8,19 & 4,993 \\
Total & 33,72 & 13,704 & 44,62 & 11,307 & 39,14 & 12,514 & 56,04 & 12,067 & 41,85 & 14,781 \\
\hline
\end{tabular}


Perbedaan Kemampuan Berpikir Logis Mahasiswa Berdasarkan Tingkat Kelas

Skor kemampuan berpikir logis tidak berdistribusi normal, baik secara keseluruhan maupun perbagian. Uji Kolmogorov-Smirnov menunjukkan nilai $\mathrm{p}<0,05$. Oleh karena itu, dilakukan uji Kruskal Wallis untuk menentukan perbedaan kemampuan berpikir logis mahasiswa calon guru kimia berdasarkan tingkat kelas. Hasil uji Kruskal Wallis (Tabel 5) menunjukkan tidak adanya perbedaan secara signifikan antara mahasiswa tingkat I, II, III dan IV ( $\mathrm{p}=0,201$ ).

Hasil serupa didapatkan untuk setiap jenis kemampuan berpikir logis, yaitu penalaran proporsional $(\mathrm{p}=0,739)$, pengontrolan variabel $(\mathrm{p}=0,265)$, penalaran probabilitas $(\mathrm{p}=0,092)$, penalaran korelasional $(\mathrm{p}=0,162)$, dan penalaran kombinatorial $(\mathrm{p}=0,560)$.

\section{Perbedaan Model Mental Mahasiswa Ber- dasarkan Tingkat Kelas}

Skor model mental kimia sekolah berdistribusi normal secara keseluruhan $(\mathrm{p}=0,372)$, tetapi tidak berdistribusi normal untuk setiap pokok bahasan. Hasil uji Kruskal Wallis (Tabel 6) untuk model mental kimia sekolah menunjukkan terdapat perbedaan yang signifikan antara mahasiswa tingkat I, II, III, dan IV ( $\mathrm{p}=0,000)$. Perbedaan yang signifikan juga ditemukan di setiap pokok bahasan yang diujikan, seperti stoikiometri $(\mathrm{p}=0,001)$, thermokimia $(\mathrm{p}=0,000)$, kesetimbangan $(\mathrm{p}=0,000)$, kecepatan reaksi $(\mathrm{p}=0,029)$, dan asam basa $(\mathrm{p}=0,003)$.

Tabel 5. Uji Normalitas dan Uji Perbedaan Rata-rata Kemampuan Berpikir Logis

\begin{tabular}{lcc}
\hline \multicolumn{1}{c}{ Kemampuan Berpikir Logis } & $\begin{array}{c}\text { Uji Kolmogorov-Smirnov } \\
(\mathrm{p})\end{array}$ & $\begin{array}{c}\text { Uji Kruskal Wallis } \\
(\mathrm{p})\end{array}$ \\
\hline penalaran proporsional & 0,000 & 0,739 \\
pengontrolan variabel & 0,000 & 0,265 \\
Penalaran probabilitas & 0,000 & 0,092 \\
Penalaran korelasional & 0,000 & 0,162 \\
Penalaran kombinatorial & 0,000 & 0,560 \\
Total & 0,013 & 0,201 \\
\hline
\end{tabular}

Tabel 6. Uji Normalitas dan Uji Perbedaan Rata-rata Model Mental Kimia Sekolah

\begin{tabular}{lcc}
\hline \multicolumn{1}{c}{ Model Mental Kimia Sekolah } & $\begin{array}{c}\text { Uji Kolmogorov-Smirnov } \\
(p)\end{array}$ & $\begin{array}{c}\text { Uji Kruskal Wallis } \\
(p)\end{array}$ \\
\hline Stoikiometri & 0,000 & 0,001 \\
Thermokimia & 0,000 & 0,000 \\
Kecepatan reaksi & 0,000 & 0,029 \\
Kesetimbangan & 0,000 & 0,000 \\
Asam basa & 0,000 & 0,003 \\
Total & 0,372 & 0,000 \\
\hline
\end{tabular}

Tabel 7. Nilai p pada Uji Mann Whitney Setiap Kelompok

\begin{tabular}{ccccc}
\hline Tingkat Kelas & Tingkat I & Tingkat II & Tingkat III & Tingkat IV \\
\hline Tingkat I & - & 0,003 & 0,145 & 0,000 \\
Tingkat II & 0,003 & - & 0,098 & 0,002 \\
Tingkat III & 0,145 & 0,098 & - & 0,000 \\
Tingkat IV & 0,000 & 0,002 & 0,000 & - \\
\hline
\end{tabular}


Tabel 8. Hasil Uji Korelasi Bivariate Spearman antara Kemampuan Berpikir Logis (KBL) Dengan Model Mental Kimia Sekolah (MKS)

\begin{tabular}{lcccccc}
\hline & $\begin{array}{c}\text { Stoikio- } \\
\text { metri }\end{array}$ & $\begin{array}{c}\text { Thermo- } \\
\text { kimia }\end{array}$ & $\begin{array}{c}\text { Kesetim- } \\
\text { bangan }\end{array}$ & $\begin{array}{c}\text { Kecepatan } \\
\text { Reaksi }\end{array}$ & Asam Basa & MKS Total \\
\hline Penalaran proporsional & 0,384 & 0,295 & 0,511 & 0,309 & 0,433 & 0,680 \\
Pengontrolan variabel & 0,214 & 0,529 & 0,602 & 0,376 & 0,204 & 0,673 \\
Penalaran probabilitas & 0,344 & 0,425 & 0,517 & 0,414 & 0,422 & 0,732 \\
Penalaran korelasional & 0,460 & 0,188 & 0,359 & 0,401 & 0,548 & 0,657 \\
Penalaran kombinatorial & 0,285 & 0,436 & 0,558 & 0,416 & 0,395 & 0,727 \\
KBL Total & 0,408 & 0,453 & 0,617 & 0,461 & 0,477 & 0,835 \\
\hline
\end{tabular}

Uji Post Hoch dari metode analitik Kruskal-Wallis yaitu Mann Whitney dilakukan untuk mengetahui perbedaan skor rata-rata model mental kimia sekolah antar tingkat kelas. Hasil uji Mann Whitney dapat dilihat pada Tabel 7.

Model mental kimia sekolah mahasiswa tingkat I berbeda secara signifikan dengan mahasiswa tingkat II $(p=0,003)$ dan IV $(p=0,000)$, namun tidak berbeda dengan mahasiswa tingkat III $(\mathrm{p}=0,145)$. Perbedaan secara signifikan juga didapatkan antara mahasiswa tingkat II dengan tingkat IV $(\mathrm{p}=0,002)$ dan antara mahasiswa tingkat III dengan tingkat IV $(\mathrm{p}=0,000)$. Mahasiswa tingkat II dengan tingkat III ditemukan tidak memiliki perbedaan model mental kimia sekolah $(\mathrm{p}=0,098)$.

\section{Korelasi Kemampuan Berpikir Logis dengan Model Mental Mahasiswa}

Hasil uji korelasi bivariate Spearman antara kemampuan berpikir logis dengan model mental kimia sekolah ditunjukkan dalam Tabel 8. Pokok bahasan stoikiometri berkorelasi kuat dengan penalaran korelasional $(\mathrm{p}=0,460)$. Thermokimia berkorelasi kuat dengan pengontrolan variabel $(\mathrm{p}=0,529)$, penalaran probabilitas $(\mathrm{p}=$ $0,425)$ dan penalaran kombinatorial $(\mathrm{p}=0,436)$. Kesetimbangan berkorelasi kuat dengan hampir seluruh jenis penalaran dan sangat kuat dengan pengontrolan variabel $(p=0,602)$. Kecepatan reaksi berkorelasi kuat dengan penalaran probabilitas $(\mathrm{p}=0,414)$, penalaran korelasional $(\mathrm{p}=$ $0,401)$, dan penalaran kombinatorial $(\mathrm{p}=0,416)$. Asam basa berkorelasi kuat dengan penalaran proporsional $(\mathrm{p}=0,433)$, penalaran probabilitas $(\mathrm{p}=0,422)$ dan penalaran korelasional $(\mathrm{p}=$ $0,548)$. Secara keseluruhan kemampuan berpi- kir logis berkorelasi sangat kuat dengan model mental kimia sekolah $(\mathrm{p}=0,835)$.

\section{Pembahasan}

Pada penelitian ini telah dideskripsikan kemampuan berpikir logis mahasiswa calon guru kimia. Hasil penelitian menunjukkan bahwa secara keseluruhan rata-rata skor kemampuan berpikir logis mahasiswa calon guru kimia sebesar 5,40 dari nilai maksimal 10, dengan simpangan baku 3,383. Sebagian besar mahasiswa dari tingkat I sampai dengan tingkat IV sudah mencapai tahap perkembangan formal atau formal akhir, namun masih ditemukan sebanyak 18,6\% mahasiswa berada pada tahap perkembangan operasional konkret. Hasil penelitian Fah (2009) juga menunjukkan bahwa 98\% mahasiswa Divisi Interior di Sabah, Malaysia, masih berada pada tahapan operasional konkret (memiliki skor antara 0-1). Hal ini tentunya berlawanan dengan Teori Perkembangan Kognitif yang diusulkan oleh Jean Piaget bahwa tahap perkembangan operasional formal akhir sudah dapat dicapai oleh anak yang berusia 11-16 tahun (Inhelder \& Piaget, 1958). Dengan demikian, hasil penelitian ini semakin memperkuat usulan Demetriou \& Efklides (1994) untuk melakukan revisi terhadap tahap perkembangan kognitif Piaget.

Hasil penelitian juga menunjukkan penalaran proporsional memiliki skor rata-rata yang paling tinggi $(M=1,20)$, sedangkan penalaran probabilitas memiliki skor rata-rata yang paling rendah $(\mathrm{M}=1,00)$. Fah (2009) menunjukkan hasil penelitian yang sama yaitu skor penalaran probabilitas paling rendah, namun skor tertinggi pada penalaran kombinatorial. Yenilmez, Su- 
ngur and Tekkaya (2005) mendapatkan skor tertinggi pada penalaran pengontrolan variabel, sedangkan terendah pada penalaran korelasional. Perbedaan ini menunjukkan bahwa perkembangan kemampuan berpikir logis setiap mahasiswa tidak sama dan tentunya tergantung dari lingkungan yang membentuknya.

Hasil uji Kruskal Wallis untuk menentukan perbedaan kemampuan berpikir logis mahasiswa calon guru kimia berdasarkan tingkat kelas, menunjukkan tidak adanya perbedaan secara signifikan antara mahasiswa tingkat I, II, III dan IV. Tuna, Biber dan Incikapi (2013:86) menunjukkan hasil yang berbeda, kemampuan berpikir logis mahasiswa calon guru matematika di salah satu universitas pendidikan di Turkey secara signifikan dipengaruhi oleh tingkat kelas. Hal ini menunjukkan proses perkuliahan dari satu tingkat ke tingkat berikutnya bagi mahasiswa calon guru kimia belum mampu memberikan sumbangan terhadap peningkatan kemampuan berpikir logis. Padahal, kemampuan berpikir logis berkorelasi sangat kuat dengan model mental kimia sekolah mahasiswa calon guru $(\mathrm{p}=0,835)$. Oleh karena itu, perlu upaya menumbuhkan kemampan berpikir logis mahasiswa baik secara tersirat dalam setiap mata kuliah maupun tersurat dalam mata kuliah tersendiri.

Pada penelitian ini juga dideskripsikan model mental kimia sekolah mahasiswa calon guru. Secara umum, mahasiswa tingkat IV memiliki skor model mental kimia sekolah paling tinggi dibandingkan tingkat kelas di bawahnya. Rata-rata skor model mental kimia sekolah adalah 41,85 dari skor maksimal 100, dengan ratarata skor tertinggi pada pokok bahasan thermokimia. Berdasarkan hasil uji korelasi bivariate Spearman, pokok bahasan thermokimia berkorelasi kuat dengan pengontrolan variabel, penalaran probabilitas, dan penalaran kombinatorial. Pengontrolan variabel sangat berperan dalam merencanakan dan melaksanakan pemecahan masalah berbagai jenis reaksi yang melibatkan energi, sebagaimana dalam thermokimia. Interpretasi data dan hasil pengamatan berbagai percobaan dalam thermokimia seringkali membutuhkan penalaran probabilistik. Terakhir, pe- nalaran kombinatorial berperan dalam merumuskan hipotesis alternatif untuk menguji efek dari variabel yang mempengaruhi penggunaan energi dalam reaksi kimia.

Berdasarkanhasil uji Kruskal Wallis yang dilanjutkan dengan uji Mann Whitney menunjukkan bahwa secara keseluruhan terdapat perbedaan yang signifikan antara mahasiswa tingkat I, II, III, dan IV, namun tidak berbeda secara signifikan antara mahasiswa tingkat I dan tingkat II dengan mahasiswa tingkat III. Dalam pokok bahasan stoikiometri, skor rata-rata mahasiswa tingkat III lebih rendah daripada mahasiswa tingkat I dan untuk pokok bahasan thermokimia, kesetimbangan dan kecepatan reaksi, skor rata-rata mahasiswa tingkat III lebih rendah daripada mahasiswa tingkat II. Hasil ini serupa dengan penelitian Yayla \& Eyceyurt (2011) yang menyatakan bahwa model mental 5 konsep dasar kimia dari mahasiswa calon guru sains tidak seluruhnya menunjukkan perbedaan yang signifikan berdasarkan tingkat kelas. Berdasarkan tinjauan kurikulum mahasiswa tingkat I dan tingkat II masih mendapatkan mata kuliah Kimia Dasar yang secara konten dapat berfungsi menguatkan penguasaan materi subjek kimia sekolah, mahasiswa tingkat III didominasi oleh mata kuliah Kimia Lanjut. Berdasarkan hasil penelitian nampak bahwa mata kuliah kimia lanjut tidak memberikan dukungan yang signifikan terhadap penguasaan materi subjek kimia sekolah.

Pada konteks pembelajaran kimia, disarankan untuk melakukan penelitian lebih lanjut terkait proses belajar mengajar yang mampu meningkatkan kemampuan berpikir logis. Hal ini menjadikan pengembangan kemampuan berpikir logis sebagai prioritas utama dalam ilmu pendidikan. Kemampuan berpikir logis memiliki peran yang mendasar dalam prestasi akademikpembelajar dan dalam mengkonstruksi konsep. Pembelajar dengan tingkat kemampuan berpikir logis yang tinggi dapat mengubah konsepsi alternatifnya dengan lebih mudah (Oliva, 2003). Penalaran proporsional cukup penting dalam aspek kuantitatif kimia, terutama untuk memahami derivasi dan penggunaan sejumlah besar hubungan fungsional dalam kimia, seperti 
pengembangan dan interpretasi data tabulasi dan grafik. Penalaran korelasional berperan sangat penting dalam perumusan hipotesis dan interpretasi data yang perlu mempertimbangkan hubungan antara variabel. Pengontrolan variabel penting dalam perencanaan, pelaksanaan dan interpretasi. Interpretasi data dari temuan, pengamatan, atau percobaan sering membutuhkan penalaran probabilistik. Terakhir, penalaran kombinatorial terjadi dalam perumusan hipotesis alternatif untuk menguji efek dari variabel yang dipilih.

\section{PENUTUP}

Kemampuan berpikir logis mahasiswa semakin meningkat berdasarkan kenaikan tingkat, namun berdasarkan uji Kruskal Wallis, menunjukkan tidak adanya perbedaan secara signifikan antara mahasiswa tingkat I, II, III dan IV. Secara umum, model mental kimia sekolah cenderung mengalami peningkatan berdasarkan kenaikan tingkat kelas, namun sedikit mengalami penurunan pada mahasiswa tingkat III. Perbedaan rata-rata skor model mental kimia sekolah nampak signifikan antara mahasiswa tingkat I, II, III, dan IV. Hasil uji korelasi bivariate Spearman menunjukkan kemampuan berpikir logis berkorelasi sangat kuat dengan model mental kimia sekolah.

\section{UCAPAN TERIMA KASIH}

Terima kasih kami ucapkan kepada Program Studi Pendidikan IPA, Sekolah Pascasarjana, Universitas Pendidikan Indonesia yang telah banyak memberikan kontribusi sehingga penelitian ini dapat berjalan dengan lancar. Terima kasih juga kami ucapkan kepada Ditjen Pendidikan Tinggi yang telah banyak memberikan dukungan dana sehingga penelitian ini dapat berjalan dengan lancar.

\section{DAFTAR PUSTAKA}

Adbo, K. and Taber, K. S. 2009. "Learners' Mental Models of the Particle Nature of Matter: a Study of 16-Year-Old Swedish Science Students". International Journal of Science Education. 31(6), 757-786.
Adey, P., \& Shayer, M. 1994. Really Raising Standards: Cognitive Intervention and Academic Achievement. London: Routledge.

Demetriou, A., \& Efilides, A. 1988. "Experiential Structuralism and Neo-Piagetian Theories: Toward an Integrated Model" dalam Demetriou, A. (Ed.), The neo-Piagetian Theories of Cognitive Development: Toward an Integration. h. 103-136. Amsterdam: North-Holland.

Fah, L. Y. 2009. "Logical Thinking Abilities among Form 4 Students in the Interior Division of Sabah, Malaysia". Journal of Science and Mathematics Education in Southeast Asia, 32(2), 161-187.

Inhelder, B. \& Piaget, J. 1958. The Growth of Logical Thinking: from Childhood to Adolescence. New York: Basic Books, Inc.

Jansoon, N. Coll, R. K. and Somsook, E. 2009. "Understanding Mental Models of Dilution in Thai Students". International Journal of Environmental \& Science Education. 4(2), 147-168.

Lawson, A. E. and Thompson L. D. 1988. "Formal Reasoning Ability and Misconceptions Concerning Genetics and Natural Selection". Journal of Research in Science Teaching. 25, 733-746.

Lin, J. W. and Chiu, M. H. 2007. "Exploring the Characteristics and Diverse Source of Students' Mental Models of Acids and Bases". International Journal of Science Education. 29 (6), 771-803.

Lin, J. W. and Chiu, M. H. 2010. "The Mismatch between Students' Mental Models of Acids/Bases and Their Sources and Their Teacher's Anticipations Thereof". International Journal of Science Education, 32 (12), 161-164. 
Oliva, J. M. 2003. "The Structural Coherence of Students' Conceptions in Mechanics and Conceptual Change". International Journal of Science Education. 25, 539-561.

Park, E. J. \& Light, G. 2009. "Identifying Atomic Structure as a Threshold Concept: Student Mental Models and Troublesomeness". International Journal of Science Education. 31(2), 233-258.

Savant, M., 1997. The Power of Logical Thinking. St. Martin's Press, New York

Strickland, A. M. Kraft, A. and Bhattacharyya, G. 2010. "What Happens when Representations Fail to Represent? Graduate Students' Mental Models of Organic Chemistry Diagrams". Chemistry Education Research and Practice. 11, 293301.

Tobin, K.G., \& Capie, W., 1981. "The Development and Validation of a Group Tes of Logical Thinking”. Educational and Psychological Measurement.41,413-423.

Tuna, A., Biber, A.C., and Incikapi, L. 2013. "An Analysis of Mathematics Teacher Candidates' Logical Thinking Levels: Case of Turkey". Journal of Educational and Instructional Studies in The World. 3, 83-91.
Valanides, N. C., 1997. "Cognitive Abilities among Twelfth-Grade Students: Implications for Science Teaching". Educational Research and Evaluation. 3, 160-186.

Wang, C. Y. and Barrow, L. H. 2010. "Characteristics and Levels of Sophistication: An Analysis of Chemistry Students' Ability to Think with Mental Models". Research Science Education. DOI 10.1007/s11165010-9180-7.

Yayla, G. \& Eyceyurt, G. 2011. "Mental Models of pre-Service Science Teachers about Basic Concepts in Chemistry". Western Anatolia Journal of Educational Sciences (WAJES), Special Issue: Selected Papers presented at WCNTSE.

Yenilmez, A., Sungur, S., Tekkaya, C. 2005. Investigating students' Logical Thinking Abilities: the Effects of Gender and Grade Level. H. Ü. Egitim Fakültesi, 28, 219-225.

Yilmaz, A. and Alp, E., 2006. "Students' Understanding of Matter: The Effect of Reasoning Ability and Grade Level". Chemistry Education Research and Practice. 7 (1), 22-31. 